JPDS (April, 2019), Vol. 2, No. 1 h.13-18

E-ISSN: 2655-2469

(C) 2019 Penulis

\title{
PENGEMBANGAN KAJIAN SEJARAH TEMATIK SEBAGAI ALTERNATIF BAHAN AJAR SEJARAH TINGKAT MENENGAH ATAS DI BLITAR
}

\author{
Ari Sapto*, Lutfiah Ayundasari, Ronal Ridhoi, Moch. Nurfahrul Lukmanul Khakim \\ ari.sapto.fis@um.ac.id
}

Jurusan Sejarah, Fakultas IImu Sosial, Universitas Negeri Malang

Diterima 4 Maret 2019, dipublikasikan 30 April 2019

\begin{abstract}
Abstrak
Tujuan kegiatan pengabdian kepada masyarakat ini adalah untuk memberikan pendampingan kepada guru sejarah di Blitar dalam rangka pengembangan bahan ajar sejarah tematik dengan materi sejarah lokal Blitar. Metode pengembangan yang dilakukan meliputi analisis kebutuhan, pelaksanaan workshop, dan pendampingan pengembangan bahan ajar. Mitra yang terlibat dalam kegiatan ini adalah guru-guru sejarah di Blitar yang tertarik dalam pengembangan bahan ajar sejarah tematik. Hasil dari kegiatan ini adalah kumpulan tulisan dari kelompok guru yang dikombinasikan dengan artikel pemateri workshop untuk dipublikasikan dalam bentuk e-book sebagai bahan ajar sejarah tematik di Blitar.
\end{abstract}

Kata Kunci: Sejarah Tematik, Bahan Ajar, Blitar

\section{PENDAHULUAN}

Dewasa ini tema-tema kajian sejarah semakin berkembang, jika pada masa lalu sejarah hanya berkisar pada orang-orang dan peristiwa-peristiwa besar maka dengan kemunculan aliran sejarah baru yang menekankan pada penerapan ilmu sosial dalam penulisan sejarah maka kajian sejarah semakin beragam. Aliran ini berkembang mula-mula di Amerika Serikat sejak 1925-an melalui sejarawan Carl L. Becker (1973-1945) dan James Harey Robinson (1863-1936), di Indonesia ia masih merupakan relatif baru; dan Kuntowijoyo adalah salah satu di antara sedikit sejarawan yang bertanggungjawab memperkenalkannya dalam skala yang lebih luas (Azra, 2005). Protes terhadap kajian sejarah lama atau sejarah tradisional juga dilancarkan oleh Marc Bloch dan Lucien Febvre dari Universitas Strasbourg dengan menerbitkan jurnal berjudul Annales d'histoire eqonomique et sociale. Kelompok ini kemudian dikenal sebagai madzhab Annales yang kajiannya mengarah pada tema-tema sosial historis. Mazhab Annales atau arus sosial-historis dalam tradisi strukturalis berkonsentrasi pada kontinuitaskontinuitas jangka panjang dalam sejarah struktur-struktur geografi, ekonomi, sosial dan kulturbercakupan luas yang tersembunyi di bawah permukaan fenomena-fenomena jangka pendek yang muncul dalam bidang sosial, politik perang, dan kegiatan-kegiatan personal sehari-hari (Azra, 1996: 199).

Dalam rangka mewujudkan hal tersebut Kartodirdjo (2016) menyatakan bahwa pendekatan dalam memahami suatu peristiwa sejarah, dapat dilakukan melalui berbagai jalur metodologis atau perspektif teoritis dan yang terpenting adalah jalan atau perspektif ekonomis, sosiologis, politikologis, dan kultural-antropologis. Jalur ini mengarah pada ilmu-ilmu sosial, karena sejarah sangat dekat ilmuilmu tersebut. Menganalisis peristiwa sejarah dengan menggunakan pendekatan ini akan mampu menyajikan peristiwa secara lebih utuh dan lebih menarik, dengan cara ini sejarah tidak hanya bertujuan untuk menceritakan kejadian tertentu tetapi juga untuk mencari sebab akibat dari segi lingkungan fisik, sosio-kultural, mental dll. Namun sayangnya, kajian-kajian seperti ini hanya berada dikalangan akademisi kampus dan belum sampai pada guru maupun siswa yang belajar di sekolah mengah. Hal inilah yang sampai saat ini juga menjadi salah satu alasan mengapa siswa merasa bahwa matapelajaran sejarah hanya berisi deretan angka, nama dan peristiwa yang harus dihafal tanpa memiliki arti.

Selama ini solusi atas masalah tersebut dilakukan dengan cara memanfaatkan media berbantuan TIK agar siswa lebih bersemangat dalam belajar. Dalam kegiatan pengabdian ini tim 
menawarkan sudut pandang baru dalam proses pembelajaran sejarah yaitu dengan merancang bahan ajar sejarah tematik yang dekat dengan lingkungan siswa, agar mereka belajar tentang sejarah secara utuh dan mampu melakukan analisis peristiwa dengan menggunakan pendekatan ilmu sosial dan sudut pandang multidimensional.

\section{METODE}

Pelaksanaan pengabdian ini dilakukan di Blitar untuk melatih guru dalam mengembangkan bahan ajar tematik. Alasan pemilihan Blitar sebagai wilayah pengabdian karena memiliki catatan perjalanan sejarah yang cukup kompleks sejak masa Hindu-Budha sampai masa kemerdekaan. Peristiwa-peristiwa yang terjadi di wilayah ini erat kaitannya dengan peristiwa skala nasional. Oleh karena itu, dalam rangka menyajikan peristiwa sejarah secara utuh kepada siswa maka diperlukan sinergi antara akademisi universitas yang sering melakukan penelitian historis dan pembelajaran dengan guru yang memiliki pengetahuan tentang kebutuhan lapangan. Pengabdian ini dilaksanakan dalam tiga tahap kegiatan yaitu analisis kebutuhan, workshop dan pembuatan bahan ajar.

\section{Analisis Kebutuhan}

Analisis Kebutuhan dilakukan dengan menyebarkan angket kepada seluruh guru MGMP yang hadir saat pengabdian. Angket ini dirancang dengan tujuan menggali informasi tentang beberapa hal antara lain latar belakang akademik, jumlah jam mengajar, ilmu terbaru yang mereka dapat, permasalahan dalam mengajar dan sejauh mana mereka mengetahui sejarah lokal di Blitar. Dalam kegiatan ini diperoleh beberapa informasi penting terkait dengan proses pembelajaran sejarah di Blitar.

Secara akademis guru-guru tersebut memiliki latar belakang pendidikan yang sesuai yaitu lulusan jurusan sejarah, 96\% diantara mereka lulus dari perguruan tinggi negeri. Dari total 27 guru yang menjadi peserta rata-rata dalam setiap minggu mereka mengajar sebanyak 29 jam. Frekuensi jam mengajar mereka berbeda antara sekolah negeri dan sekolah swasta, untuk sekolah negeri antara 2840 jam sedangkan sekolah swasta antara 7-12 jam per minggu. Tingginya jumlah jam mengajar ternyata merupakan masalah yang banyak dihadapi oleh mereka terutama jika jam mengajar terletak diakhir jam pelajaran, namun hal ini dapat diatasi dengan penggunaan strategi pembelajaran yang merangsang aktivitas siswa. Kesulitan lain yang mereka hadapi adalah terbatasnya sumber atau bahan ajar baik untuk sejarah nasional maupun sejarah lokal. Selama ini dalam proses pembelajaran mereka menggunakan buku guru, buku siswa dan LKS sebagai sumber belajar sejarah. Keterbatasan sumber belajar ini membuat pembelajaran sejarah kurang menarik. Jika sejarah tidak menarik untuk dibaca, maka tidak akan pernah ada yang mau belajar sejarah (Khakim, 2016:92-93). Hal ini tentu saja tidak dapat mengakomodir kebutuhan akan kajian sejarah lokal Blitar yang memiliki kaitan erat dengan sejarah nasional Indonesia. Oleh karena itu, kegiatan pengabdian ini dilaksanakan dalam rangka menyelesaikan permasalahan guru tentang kurangnya ketersediaan bahan ajar atau sumber belajar terutama untuk kajian sejarah lokal.

Berdasarkan hasil analisis angket ditemukan bahwa guru-guru tersebut pada pasarnya telah memiliki pengetahuan awal tentang peristiwa-peristiwa dan situs-situs sejarah yang berada di Blitar. Beberapa diantaranya adalah: (1) Situs Candi Penataran atau Candi Palah; (2) Perlawanan Supriyadi yang menjadikan Blitar dikenal sebagai Kota Patria; (3) Situs Monumen Trisula; (3) Perkebunan kopi masa pemerintah kolonial Belanda; (4) Situs Candi Simping; (5) Sejarah kuliner Blitar "Roti Orion"; (6) Situs Museum Bung Karno; (7) Tokoh-tokoh besar dari Blitar dll.

Pengetahuan awal ini merupakan indikator ketertarikan mereka terhadap sejarah lokal hanya saja guru-guru ini tidak memiliki waktu maupun rekan yang dapat membimbing mereka dalam menghasilkan sebuah karya tentang sejarah lokal. Berdasarkan kondisi tersebut maka dirancang kegiatan workshop pengembangan bahan ajar tematik dalam lingkup lokal Blitar. Sejarah tematik dipilih karena dapat menjadi payung bagi jenis-jenis kajian yang mereka inginkan.

\section{Workshop}

Setelah kegiatan analisis kebutuhan dilakukan dan ditemukan permasalahan yang dihadapi oleh guru sejarah di Blitar, tim pengabdian merancang kegiatan workshop pada tanggal 9 Mei 2018 di SMAN 2 Blitar dengan tema "Peningkatan Profesionalisme Guru melalui Pengembangan Bahan Ajar Tematik". 
Kegiatan ini dikemas dalam dua sesi yaitu penyajian materi dan pendampingan merancang bahan ajar tematik secara berkelompok. Dalam kegiatan ini terdapat tiga pemateri dari Jurusan Sejarah Universitas Negeri Malang yaitu Dr. Ari Sapto, M.Hum yang menyajikan materi tentang "Sejarah Lokal di Kawasan Blitar", Moch. Nurfahrul Lukmanul Khakim dengan materi tentang "Bahan Ajar dan Profesionalime Guru". Sajian materi ini ditutup oleh Ronal Ridho'i, S. Hum, M.A yang membahas tentang "Sejarah Tematik dalam Pembelajaran Sejarah".

\section{Pembuatan Bahan Ajar}

Pembuatan bahan ajar dimulai dengan penyusunan kerangka sejarah tematik mengenai Blitar. Para pemateri mendampingi para guru dalam menyusun kerangka bahan ajar sejarah tematik. Setiap pemateri mendampingi kelompok guru yang menyusun kerangka bahan ajar sejarah tematik. Kerangka bahan ajar dapat dijadikan landasan para guru dalam mengembangkan ide tulisan bahan ajar sejarah tematik. Bahan ajar sejarah tematik ini dikerjakan dalam waktu satu bulan. Proses review bahan ajar sejarah tematik ini akan dilakukan secara online oleh tim pengabdian. Pada akhir pembuatan bahan ajar terkumpul lima bahan ajar sejarah tematik dengan lingkup kajian sejarah lokal di Blitar. Kumpulan bahan ajar sejarah tematik ini disempurnakan akan dijadikan satu dalam bunga rampai. Hasil kerja kelompok guru ini dijadikan e-book ber-ISBN dan digunakan sebagai bahan ajar sejarah di Blitar.

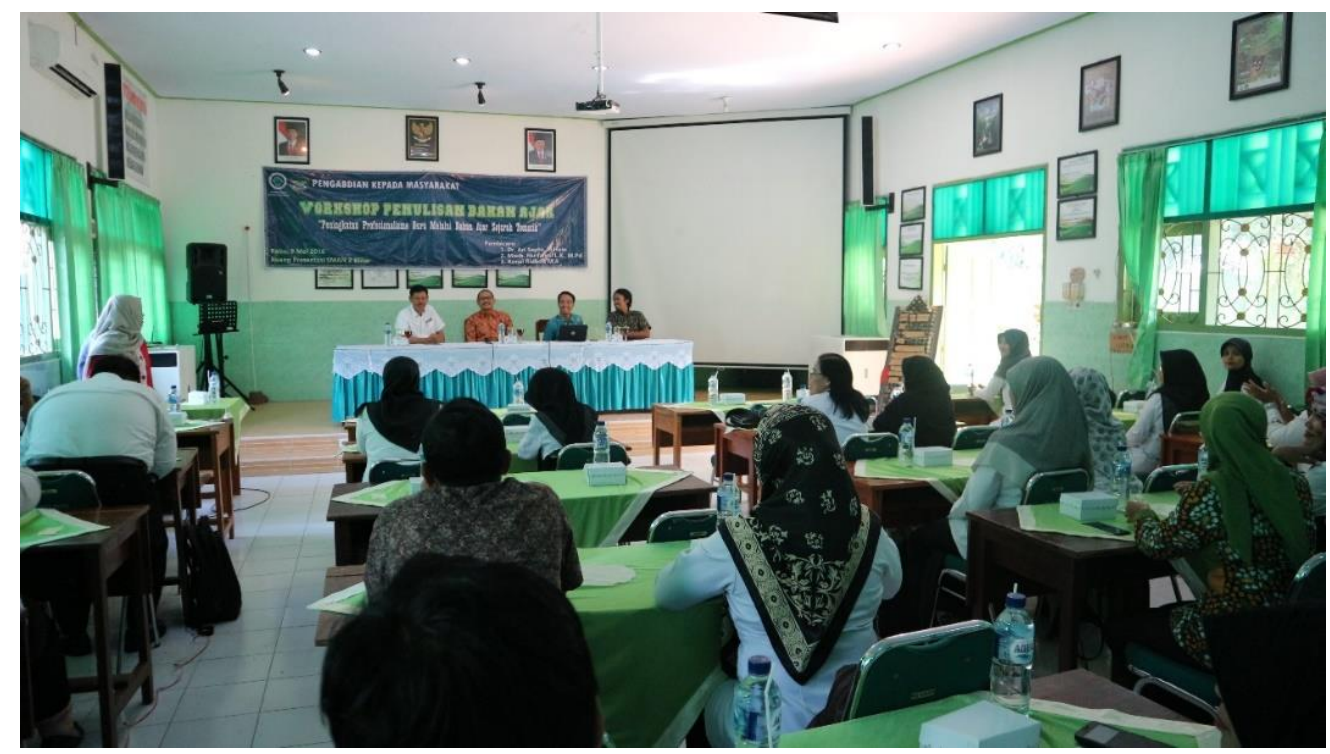

Gambar 1. Penyajian materi workshop oleh dosen Jurusan Sejarah

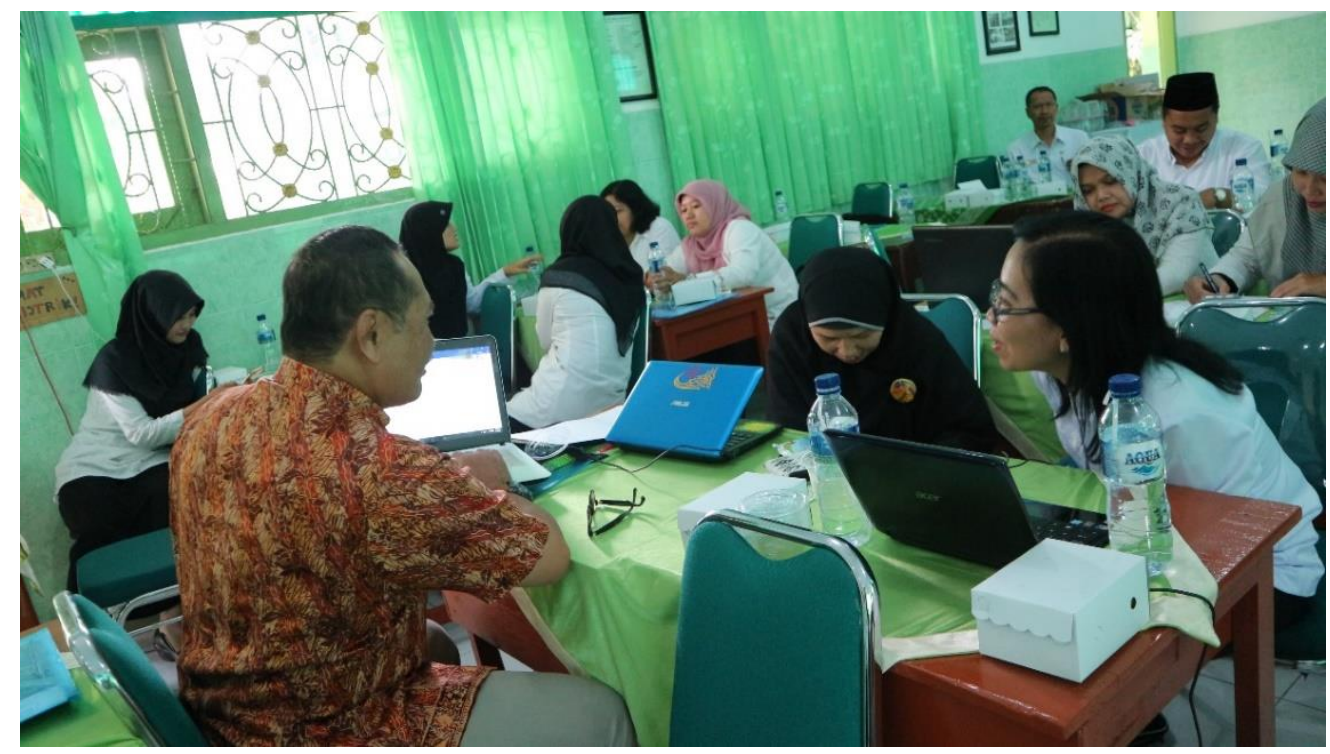

Gambar 2. Proses pendampingan perancangan bahan ajar tematik oleh salah satu pemateri 


\section{HASIL DAN PEMBAHASAN}

Sejarah tematik yang digunakan untuk mengkaji peristiwa-peristiwa lokal merupakan hal yang cukup menarik untuk dikembangkan, tidak hanya pada ranah keilmuan tetapi juga pendidikan dan pembelajaran di sekolah. Apalagi ruang untuk mengajarkan materi ini terbuka lebar dengan diberlakukannya kurikulum 2013 di SMA. Pada kurikulum ini matapelajaran sejarah dibagi dua yaitu wajib dan peminatan, melalui pembelajaran sejarah peminatan inilah guru-guru dapat memasukkan materi sejarah tematik dalam lingkup lokal. Dalam rangka memenuhi kebutuhan tersebut maka salah satu hal dapat dilakukan adalah memberikan pendampingan kepada guru-guru sejarah untuk turut aktif menuliskan sejarah tematik dilingkungan mereka. Kajian sejarah lokal seperti ini tidak hanya berdampak positif terhadap ketersediaan sumber belajar tetapi juga mampu meningkatkan minat, motivasi, hasil belajar siswa dan empati siswa pada kekayaan sejarah dan budaya yang terdapat di daerahnya (Hastuti 2013, Sudiartuti 2015, Wibowo 2017). Selain itu, kajian terhadap sejarah lokal juga memiliki beberapa fungsi antara lain; pertama, mendekatkan materi pelajaran dengan lingkungan peserta didik agar pembelajaran sejarah bermakna; kedua, peserta didik tidak tercerabut dari akar budayanya; ketiga, menciptakan kebanggaan dan keterikatan yang berdampak pada munculnya rasa tanggungjawab untuk ikut menjaga dan memajukan lingkungan; keempat, menumbuhkan minat wirausaha dari hasil pengamatan dan refleksi terhadap lingkungan sekitar; kelima, sebagai salah satu langkah glokalisasi agar kedepan mereka mampu memposisikan diri sebagai masyarakat yang berdaya saing dengan memanfaatkan potensi lokal (Ayundasari, 2017:218). Kegiatan workshop pengembangan bahan ajar tematik dengan materi sejarah lokal diharapkan mampu memberikan efek seperti tersebut.

Workshop dan pendampingan penulisan bahan ajar tematik yang dilaksanakan di Blitar mendapat respon yang cukup baik. Hal ini ditunjukan dengan kesediann kelompok guru untuk menyusun bahan ajar tematik dengan sukarela. Pada akhir kegiatan pengabdian terkumpul lima artikel yang dapat digunakan sebagai bahan ajar bagi guru sejarah di Blitar. Artikel pertama dari pengabdian ini yaitu tulisan Alfi Syahrina dan Florensia Tyastuti dkk tentang lembaga pemasyarakatan anak yang ada di Blitar. Kajian ini mencoba membahas perkembangan Lembaga Pembinaan Khusus Anak (LPKA) yang berada di Blitar. LPKA di Blitar ini sudah berdiri sejak Zaman Hindia Belanda. Tidak semua kota memiliki LPKA, sampai dengan saat ini tercatat setiap provinsi hanya memiliki satu LPKA. Dengan demikian LPKA Blitar merupakan satu-satunya LPKA yang dimiliki Propinsi Jawa Timur. Membahas LPKA berarti membahas perkembangan anak. Kajian ini sangat penting untuk dibahas lebih lanjut, karena permasalahan anak dan juga lembaga yang menaunginya masih jarang dibahas dalam sejarah Indonesia.

Artikel kedua yaitu tulisan Hanifitria Ningrum dkk yang membahas arsitektur dan silang budaya Masjid Agung Kota Blitar. Tema seperti ini sudah sering dibahas dalam historiografi Indonesia maupun karya tulis ilmu Arkeologi dan Arsitektur. Namun, yang berbeda adalam penekanan tulisan ini tidak hanya pada arsitektur, tapi juga pada akulturasi atau silang budaya antara kearifan lokal dengan Agama Islam. Jadi proses Islamisasi dan tokoh-tokohnya di daerah pedalaman Blitar akan menarik jika dihubungkan dengan tinggalan masa lalunya yang berupa masjid.

Artikel ketiga yaitu tulisan Eko Hadi Susilo, dkk, tentang Tugu Rante di Blitar sebagai monument pengingat meletusnya Gunung kelud. Tulisan tersebut mencoba menghadirkan pertanyaan mendasar mengenai kenangan yang tersimpan dalam monument "tugurante" Sanankulon Blitar, secara nyata terpahat sepengal kalimat tentang Kelud 1919. Pembahasan utama yaitu gambaran peristiwa meletusnya Gunung Kelud serta kondisi masyarakat di sekitarnya pada saat itu dampaknya terhadap kondisi sosial masyarakat. Selain itu juga membahas makna tugu tersebut dan bagaimana masyarakat sekitar mengingatnya. Tema ini merupakan kajian baru dalam penulisan sejarah Indonesia. Kajian tentang politik memori terkait situs maupun bangunan penanda peristiwa masa lalu merupakan hal unik yang menarik dibahas.

Artikel keempat yaitu tulisan Florensia Tyastuti dkk tentang simbol toleransi umat beragama di masa lalu, khususnya di Kabupaten Blitar. Tulisan ini merupakan salah satu kajian penting sebagai upaya menginternalisasi kebhinekaan (homo homini socius) sebagai sesuatu yang indah karena memberi warna - warni keindahan dalam perbedaan. Sebagai contoh nyata di desa Gaprang Kabupaten Blitar ada Masjid, Gereja, dan Pura yang menggambarkan suasana masyarakat Desa 
Gaprang selalu menjaga dan memelihara kerukunan antar umat beragama. Oleh karena itu jangan ada yang berpikir bahwa sesamaku adalah acaman bagiku bahkan musuh (homo homini lupus) bahwa sesungguhnya tidak ada gunanya hidup bersama dalam keberbedaan. Apalagi jika orang berpikir dan bertindak bahwa sesama yang lain diluar diriku, diluar sukuku, diluar agamaku, diluar kelompokku atau golonganku harus dihilangkan atau dibasmi di muka bumi. Pada hal jika kita rukun kita akan kuat sebagai keluarga, sebagai anggota masyarakat dan lebih luas sebagai warga negara Indonesia. Indonesia bersaudara (homo homini Socius) dalam kebhinekaan. Karya tulis ini merupakan hasil wawancara penulis dengan Bapak Mursalim seorang pemimpin sembahyang umat Hindu (tokoh agama umat Hindu). Penulis membatasi diri pada sejarah berdirinya Pura Tri Buwana dan perkembangan umat Hindu dalam menjaga dan memelihara kerukunan dan kedamaian hidup, dan MasGaPur adalah sebuah personifikasi toleransi kehidupan umat beragama di Desa Gaprang Blitar.

Artikel kelima yaitu tulisan Ika Sambita Girinandi, dkk tentang industri kerajinan Kendang Jimbe di Blitar. Tema besar yang diusung yaitu sejarah kerajinan Kendang Jimbe. Khususnya yang menjadi studi kasus adalah Desa Santren yang berada di Kelurahan Tanggung, Kecamatan Kepanjen Kidul, Kota Blitar, Provinsi Jawa Timur. Hal itu dilakukan karena di Desa Santren terdapat suatu perindustrian kerajinan asing yang kemudian dijadikan acuan sebagai sumber mata pencaharian masyarakat setempat. Untuk menganalisis hal tersebut dibutuhkan suatu pemahaman dan pengetahuan yang konkret mengenai sejarah, perkembangan, dampak, jumlah dan pemasaran kendang Jimbe tersebut. Berdasarkan latar belakang masalah tersebut, maka penelitian ini bertujuan untuk mengkaji sejarah Kendang Jimbe dan menganalisis bukti-bukti sejarah yang mendukung perkembangan Kendang Jimbe. Tema ini termasuk baru dalam khazanah historiografi Indonesia, karena kajian industri kecil atau industri kerajinan masih jarang dibahas dan cenderung terpinggirkan.

\section{Manfaat Pengembangan Kajian Sejarah Tematik bagi Pembelajaran Sejarah}

Secara garis besar pendekatan pembelajaran sejarah dibagi dalam dua kelompok yaitu pembelajaran sejarah kronologis dan tematis (Williams, 2016: v). Di Indonesia sampai saat ini secara resmi pemerintah masih menerapkan kurikulum matapelajaran sejarah secara kronologis, padahal dibeberapa negara maju pembelajaran sejarah sudah dikemas dengan pendekatan tematik. Perubahan pendekatan ini dikarenakan kritik yang disampaikan para ahli melalui hasil penelitain mereka. Kelemahan tersebut antara lain (1) belum mempu mendukung terciptanya kontekstualitas dalam pembelajaran; (2) rendahnya tingkat kedalaman dan keluasan materi; (3) hanya memberikan pengetahuan sekilas tentang peristiwa sejarah; dan (4) kurang mendukung tumbuhnya kemampuan berpikir historis diantara siswa (White 1995, Tew 2014).

Berdasarkan kelemahan tersebut alangkah baiknya jika pemangku kebijakan melakukan evaluasi pelaksanaan pembelajaran sejarah. Bukan rahasia lagi jika selama ini siswa seringkali merasa bahwa matapelajaran sejarah hanya deretan nama, angka dan peristiwa yang harus dihafal. Meskipun pendekatan tematik belum diberlakukan secara resmi, setidaknya dengan dibukanya ruang belajar sejarah peminatan dalam kurikulum 2016 maka guru memiliki kesempatan untuk menyajikan materi sejarah sesuai dengan tema-tema yang ada dilingkungan belajar siswa. Penggunaan pendekatan tematik diharapkan mampu menghadirkan kontekstualitas kajian dalam ruang kelas sehingga siswa merasakan manfaat belajar sejarah dan tidak asing dengan apa yang mereka pelajari.

Manfaat lain yang dapat diperoleh dengan menerapkan pendekatan tematik dalam pembelajaran sejarah adalah (1) menumbuhkan kemampuan berpikir historis; (2) mengeskplorasi dan mengidentifikasi ide-ide dasar dan latar belakang sebuah peristiwa; (3) memperkuat pemahaman atas tema dan konsep-konsep sejarah; (4) tidak dibatasi waktu; (5) meningkatkan partisipasi siswa; (6) melatih siswa untuk berpikir terbuka (Singer 2015, Tew 2014, Williams 2016, White 1995).

\section{KESIMPULAN}

Kajian sejarah dikalangan akademisi telah berkembang tidak hanya sebatas sejarah politik yang menarasikan tokoh-tokoh dan peristiwa-peristiwa besar tetapi juga mengungkap peran-peran elemen masyarakat dengan sudut pandang multidimensi. Hal ini sebagai dampak dari munculnya aliran Sejarah Baru dan Madzhab Annales dimana peristiwa sejarah dipahami dari berbagai jalur metodologis atau perspektif teoritis baik jalur ekonomis, sosiologis, politikologis, maupun kultural-antropologis. 
Wujud dari penggunaan analisis ini adalah munculnya sejarah tematik yang mampu menyajikan peristiwa sejarah secara utuh. Meskipun kurikulum matapelajaran sejarah di Indonesia belum mengakomodir pendekatan tematik, namun penyampaian materi ini dapat dilakukan pada matapelajaran sejarah peminatan. Hal ini dilakukan untuk merevitalisasi proses pembelajaran sejarah agar lebih memiliki arti. Oleh karena itu perlu adanya sinergi antara kelompok akademisi dan guru untuk merancang bahan ajar tematik yang kontekstual.

Kegiatan pengabdian yang dilakukan di Blitar mampu memotivasi guru mengembangkan bahan ajar tematik dengan berlatar belakang sejarah Blitar. Diharapkan hasil pengembangan bahan ajar yang berupa artikel dapat dikompilasikan menjadi book chapter dan menjadi bahan ajar berwawasan sejarah lokal Blitar.

\section{DAFTAR PUSTAKA}

Ayundasari, L. 2017. Urgensi Pembelajaran Sejarah Berbasis Potensi Lokal Bahari untuk Menumbuhkan Minat Wirausaha di Pesisir Selatan Kabupaten Malang. Jurnal Sejarah dan Budaya, Tahun Kesebelas, Nomor 2, Desember 2017, hal 211-219.

Azra, A. 2005. Konsep Kesejarahan Kuntowijoyo (Pentingnya Imajinasi, Emosi, Intuisi, dan Estetika Bahasa yang Khas dalam Penulisan Sejarah). Ibda` | Vol. 3 | No. 2 | Jul-Des 2005 |170-177

Azra, A. 1996. Islam di "Negeri Bawah Angin" dalam Masa Perdagangan (Book Review). Jurnal Studia Islamika, Vol. 3, No. 2 1996, pp 191-221

Hastuti, D. 2014. Peningkatan Minat Belajar Sejarah Siswa Melalui Penerapan Model Pembelajaran Discovery-Inquiry Berbasis Studi Keilmuan Sejarah dan Budaya Batik Lokal Lasem pada Materi Akulturasi Budaya bagi Siswa Kelas X MIA 7 SMA Negeri 1 Rembang. Jurnal Media Penelitian Pendidikan. Vol 8, No 1

Kartodirdjo, S.2016. Pendekatan Ilmu-ilmu Sosial dalam Metodologi Sejarah. Yogyakarta: Ombak

Khakim, Moch. Nurfahrul Lukmanul. 2019. Telaah Penulisan Karya Sastra sebagai Refleksi Sumber Pembelajaran Sejarah. Jurnal Sejarah dan Budaya, X, No. 1, Juni 2016 (Hal. 89-94)

Sudiartuti, L. 2015. Pengaruh Pembelajaran Sejarah Lokal: "Peristiwa Pertempuran Ciseupan 4 Pebruari 1949" terhadap Motivasi dan Hasil Belajar. Jurnal Pendidikan IImu Sosial Vol 24, No 1,

Tew, D. J. (2014, June). Pedagogy of Teaching History: Comparing the Chronologic and Thematic Approaches (2014). Diambil dari Digital Commons @ Western Oregon University: http://digitalcommons.wou.edu/honor thesis

White, R.M. 1995."How Thematic Teaching Can Transform History Instruction." Clearing House 68.3 (: 160-63. Online. Published by: Taylor \& Francis, Ltd 2016

Wibowo, T.U.S.H. 2017. Membangun Literasi Sejarah Lokal di Kalangan Siswa melalui Pembelajaran Sejarah Berbasis Keunikan Toponimi Kawasan Banten Lama. The 1st International Conference on Language, Literature and Teaching. Universitas Muhammadiyah Surakarta, April 4th - 5th 2017

Williams, S. 2016. Teaching History: Effective Teaching for Learning History - Chronological vs. Thematic Approaches to Student Historical Comprehension. Thesis. Dordt College 